\title{
New species and combinations in the genera Gyromitra, Helvella and Otidea
}

\author{
Harri Harmaja \\ Botanical Museum, University of Helsinki, SF-00170 Helsinki, Finland
}

\begin{abstract}
HARMAJA, H. 1976: New species and combinations in the genera Gyromitra, Helvella and Otidea. - Karstenia 15:29-32.

The following six new species of the Pezizales are described: Helvella pocillum Harmaja, Otidea tuomikoskii Harmaja, O. nannfeldtii Harmaja, O. papillata Harmaja, O. formicarum Harmaja and $O$. myosotis Harmaja. The following six new combinations are made: Gyromitra accumbens (Rahm) Harmaja, G. geogenia (Rahm) Harmaja, G. intermedia (Benedix) Harmaja, G. larryi (McKnight) Harmaja, Otidea microspora (Kanouse) Harmaja and O. propinquata (Karst.) Harmaja. The generic concept of Gyromitra Fr. is also discussed in brief, and a few new observations on characters of species of this genus are presented.
\end{abstract}

\section{Gyromitra Fr.}

Four species described as belonging to the Discina group are transferred to the genus Gyromitra Fr. below. Gyromitra is here acknowledged in the widened sense presented in HARMAJA 1973. Since then even more facts have accumulated that confirm that the Discina and Neogyromitra groups are best included in Gyromitra - or, at least these facts do not support the presence of generic hiatus between the esculenta-infula group (Gyromitra s. str.) and the first-named two species groups. These facts are as follows: (1) the spore surface of species belonging to all three groups is ornamented when observed under the scanning electron microscope, any differences being quantitative rather than qualitative in character (MCKNIGHT \& BATRA 1974; my own unpublished studies), (2) the responses of different parts of mature spores to heated congo red (in $5 \% \mathrm{KOH}$ ) are the same: perisporium and inner layer of wall proper are congophobic while outer layer of wall is congophilic (the results of my recent studies reported here for the first time; $G$. esculenta, G. gigas, G. melaleuca, G. perlata and G. tasmanica were examined), (3) the responses of different parts of mature spores to heated acetocarmine are the same: perisporium weakly carminophilic but wall proper carminophobic (my own studies reported here for the first time; G. ambigua, G. esculenta, $G$. tasmanica, G. korfii and G. perlata were examined), (4) the nuclei of mature spores are carminophobic (results of my studies as above; G. ambigua, G. esculenta, G. tasmanica, G. korfii and G. perlata were examined), (5) to the contrary of my previous report the red particles of asci when mounted in $\mathrm{KOH}$ (HARMAJA 1973: 55) are present, besides the esculenta group, also in the Neogyromitra group (in G. montana: own observation), (6) likewise the yellow granular contents of the paraphyses as observed in $\mathrm{KOH}$ (HARMAJA 1973: 55) have now been observed by me to occur at least occasionally also in the esculenta group (in G. esculenta), and (7) thin ephemeral layer of textura angularis is present at the surface of the excipulum in species 
belonging to all three groups (MCKNIGHT 1969 and 1971; HARMAJA 1976).

Gyromitra accumbens (Rahm) Harmaja, n. comb. (Discina accumbens Rahm, Schweizerische Zeitschr. Pilzk. 48: 80. 1970.)

Gyromitra geogenia (Rahm) Harmaja, n. comb. (Discina perlata var. geogenius Rahm,
Schweizerische Zeitschr. Pilzk. 48: 79. 1970.).

Gyromitra intermedia (Benedix) Harmaja, $\mathrm{n}$. comb. (Paradiscina intermedia Benedix, Kulturpflanze 17: 264. 1969.).

Gyromitra larryi (McKnight) Harmaja, n. comb. (Discina larryi McKnight, Michigan Bot. 13: 52. 1974.)

\section{Helvella St.-Amans}

Helvella pocillum Harmaja, n. sp. - Helvellae leucomelaenae affinis, ab ea differt apotheciis minoribus brunneis, apicibus contentiaque paraphysium dissimilibus et sporis maioribus (ca. 25.0-28.0 $\times 13.0-16.5 \mu \mathrm{m}$ ). - Typus: Sweden, prov. Torne Lappmark, par. Jukkasjärvi, fjeld Låktatjåkko, on bare soil, 194608-17, Lennart Holm 472, as H. acetabulum det. H. Dissing 1965 (UPS).

This new species, apparently alpine and/or subalpine in occurrence, differs from the related $H$. leucomelaena (Pers.) Nannf. in several respects. The most important of them are: the almost sessile apothecia of $H$. pocillum are smaller (ca. 1.0-1.5 cm high and broad), the exterior of the cup is rather dark brown, the ectal excipulum is more distinctly differentiated and is composed of larger cells, the paraphysis tips are broader, 6.5-11.0 $\mu \mathrm{m}$, the uppermost very long cells of the paraphyses are filled with conspicuous dark red-brown granules, the asci - which are eight-spored are broader $(18-25 \mu \mathrm{m})$ and their walls thicker (ca. 1.0-1.4 $\mu \mathrm{m}$ ), and the spores are larger measuring (22.0-) 25.0-28.0 (-30.0) $\mathrm{x}$ 13.0-16.5 $\mu \mathrm{m}$. The distribution of $H$. pocillum will possibly also prove more northern and correspondingly higher-situated in mountains. From $H$. crassitunicata Weber the new species is separated especially through its larger spores, broader paraphysis tips and the absence of the thick-walled setoid type of paraphyses.

$H$. pocillum is a noteworthy species as its apothecia are among the smallest ones in the genus while its spores are among the largest ones! The type was incorrectly reported as $H$. acetabulum (St.-Amans) Quél. by DISSING (1966). A thorough description of the species will be given on another occasion.

\section{Otidea (Pers.) Bon.}

Otidea tuomikoskii Harmaja, n. sp. Apothecia scissa, ad lateram oppositam elongata, extus brunneola et minutissime echinulata; hymenio flavido. Paraphyses uncinati, leniter incrassati et cum nonnullis gibbis ad apicem. Sporae oblongo-ellipsoideae, 9.0$11.0 \times 5.0-5.7 \mu \mathrm{m}$. - Typus: Finland, prov. Etelä-Häme, par. Lammi, Pappilankylä, Koiransuolenoja, in needles of Picea abies in ant hill, 1972-09-01, Risto Tuomikoski (H).

This new species is named in the honour of Dr. Risto Tuomikoski, Emeritus Professor of Biological Taxonomy, Helsinki. Besides having himself carried out taxonomic work on larger fungi, he has also contributed to the knowledge of Finnish fungi by donating to the Botanical Museum of the University of Helsinki a great many unusually representative and well-preserved specimens of macrofungi, including the type of Otidea tuomikoskii.
The apothecia of the present species are gregarious to cespitose, pronouncedly and rather narrowly ear-shaped, ca. 2-6 cm high and $0.5-2.5 \mathrm{~cm}$ broad, externally rather pale yellowish-brown and very finely echinulate, internally pale yellowish. The basal tomentum possesses a pale rusty tinge (at least when dry; most probably also in the fresh condition). The paraphysis tips are hooked, \pm enlarged, up to $5.0 \mu \mathrm{m}$ thick, and almost all, or at least most, of them possess 1-4 protuberances on the concave side. Under ultra-violet light of a wave-length of $254 \mathrm{~nm}$ the exterior of dried apothecia is dark brown while the dry hymenium is bright pale yellow. O. tuomikoskii may somewhat favour decaying parts of ant hills as habitat.

The species is easily distinguished from the O. leporina (S.F. Gray) Fuck. group especially by its light yellowish hymenium, lightly rusty- 
tinted basal tomentum, the pale pure yellow fluorescence of its dried hymenium under UV light, and the distinctly smaller spores. In well-dried ascocarps the hymenial colour mentioned is preserved almost unchanged (possibly even getting somewhat deeper which may also be true as concerns the external colour) while the hymenium displays a yellowish buff to pale brown tinge in fruit bodies dried in less appropriate manner. In well-dried apothecia there is a fairly beautiful contrast between the light yellow to butter yellow colour of the hymenium and the rusty brown of the sterile surface.

A more detailed description of $O$. tuomikoskii - as well as the other Otidea species treated in the present contribution - will be given in another paper.

\section{Specimens examined}

FINLAND. Varsinais-Suomi: Karkkila, Tuorila, coniferous forest among moss, 1954-08-26, O. v. Schulmann (H). - Etelä-Häme: Lammi, Kinnaila, Revasvuori, spruce-dominated forest, in old ant hill in spruce needles, 1971-09-04, H. Harmaja (H); Lammi, Pappilankylä, 1972-09-01, R. Tuomikoski (type; H); Lammi, Onnenvuori, spruce-dominated mesic heath forest with grass-herb character (OMT), in ant hill in spruce needles, 1973-09-06, H. Harmaja (H). - Kuusamo: Kuusamo, Liikasenvaara, Sirkkapuro, 1974-08-22, R. Tuomikoski (H).

Otidea nannfeldtii Harmaja, n. sp. - Otideae tuomikoskii sat similis; $a b$ ea differt superficie exteriori apothecii subglabro, sporis crassioribus (crassitudine 5.4-6.4 $\mu \mathrm{m}$ ) et apicibus paraphysium dissimilibus. - Typus: Finland, prov. Ahvenanmaa, par. Lemland, Nåtö, spruce forest near ơvergård, 1972-09-17, Carl-Adam Haeggström (H).

The present species is named in the honour of Dr. Johan Axel Nannfeldt, Emeritus Professor of Botany, Uppsala, whose contributions to the taxonomy of the Discomycetes, so remarkable in quantity and quality, have also concerned the genus Otidea.

This species differs from $O$. tuomikoskii, a species which it somewhat resembles, through the subglabrous (even under a handlens!) outside of its apothecia, the broader and also slightly shorter spores, measuring $9.0-10.0 \times 5.4-6.4 \mu \mathrm{m}$, and the kind of the paraphysis tips. Most of the latter, always hooked to varying degree, are gradually somewhat enlarged, 3.0-3.5 $\mu \mathrm{m}$ thick, and smooth, the rest of the tips being rather abruptly moderately enlarged to subcapitate reaching a thickness of $5.0 \mu \mathrm{m}$ at most; apart from that eventual apical swelling, only a minority of all tips possess 1-2 usually low and indistinct protuberances on the concave side.

Otidea papillata Harmaja, n. sp. - Apothecia scissa, ad lateram oppositam elongata; in statu sicco superficie exteriori alutaceo et papillato, hymenio pallido. Paraphyses uncinati, apice saepe leniter incrassato. Sporae oblongae, 9.2$10.5 \times 5.5-6.0 \mu \mathrm{m}$. - Typus: Finland, prov. Kainuu, par. Paltamo, Melalahti, Myllymäki, predominantly coniferous grass-herb forest on distinctly calcareous soil, in litter mainly composed of spruce needles, 1971-09-23, H. Harmaja (H).

The colours of fresh apothecia of this species are unfortunately not known in precise. Most probably, however, the exterior is pale yellowish brown and the hymenium pale yellowish. Anyway, in the dried condition O. papillata is easily recognized through the alutaceous sterile surface which is covered by minute dark brown papillae. The external surfaces of probably all Otideas bear some kind of delicate unevenness, but in $O$. papillata the warts are more conspicuous than in any other species known to me. This results from the fact that the papillae at the same time are unusually large for an Otidea and much darker than the ground colour (which is about the same as that of the exterior of dried O. alutacea (Fr.) Bres.). The hymenium is very pale in the dried condition displaying a very pale brownish tinge. The tips of the paraphyses are all hooked and reach a maximal thickness of $4.0 \mu \mathrm{m}$; most of them are slightly enlarged rather gradually while some proportion are enlarged \pm abruptly being thus subcapitate. A minority of the enlarged tips possess 1-3, mostly low and indistinct, protuberances on the concave side. Under ultra-violet light $\left(U_{254}\right)$ the dried apothecia display exactly the same responses as those of O. tuomikoskii.

Otidea formicarum Harmaja, n. sp. Apothecia scissa, truncatä, omnino ochraceolutea. Paraphyses apicibus curvatis vel uncinatis 2.5-5.0 $\mu \mathrm{m}$ crassis. Sporae 8.5-10.0 $x$ 5.2-6.2 $\mu \mathrm{m}$. - Typus: Finland, prov. EteläKarjala, par. Miehikkälä, Savanjärvi, in ant hill in spruce forest W of Lähdelampi, 1970-0926, Lars Fagerström (H). - Specimina alia: Etelä-Karjala: Miehikkälä, as the type, 197408-21, L. Fagerström (H); Vehkalahti, Pyhäl- 
tö, 1973-09-15, L. Fagerström (H). - Satakunta: Lappi, Lapinkylä, 1957-10-06, H. Săltin (H). - Etelä-Häme: Tammela, Syrjä, 1892-09-?, P. A. Karsten (H).

This beautiful new species is in the dried condition characterized mainly by the following features: apothecia split, truncate (i.e., not elongated on one side), rather bright ochraceous yellow on both sides; basal tomentum whitish; context thin; under UV254 exterior pale orange, hymenium bright pale yellow to slightly deeper yellow; paraphyses curved to hooked a few being straight, their tips \pm clavate, 2.5-5.0 $\mu \mathrm{m}$ thick, smooth or with one (rarely two) protuberance; spores 8.5$10.0 \times 5.2-6.2 \mu \mathrm{m}$, narrowly ellipsoid to oblong. $O$. formicarum occurs cespitose in ant hills.

Otidea myosotis Harmaja, n. sp. - Apothecia incisa, rotunda, aurem muris in mentem revocant, omnino cinnamomea. Apices paraphysium uncinati, gibbosi, partim ramulosi. Sporae 11.0-13.0 × 7.0-7.5 $\mu \mathrm{m}$. - Typus: Finland, prov. Etelä-Karjala, par. Vehkalahti, Pyhältö, Ämmänmäki, in spruce needles, 1970-10-03, Lars Fagerström (H). - Specimina alia: Varsinais-Suomi: Pohja, Brunkom, 1965-10-02, H. Såltin (H); Vihti, Vihtijärvi, 1972-09-26, R. Tuomikoski (H). - EteläKarjala: Vehkalahti, Pyhältö, 1970-10-11, L. Fagerström (H); d:o, Pyhältö, 1970-10-17, L. Fagerström (H). - Etelä-Häme: Heinola rural commune, Myllykylä, 1970-10-04, V. Haikonen (H).

This species is in the dried condition recognized especially through the following characters: apothecia cinnamon on both sides, split being truncate (i.e., not elongated) at first then expanding to become rounded and like a mouse's ears ('myos otis' in Greek); basal tomentum white; context thin and soft; under
$\mathrm{UV}_{254}$ exterior dark reddish brown, hymenium pale brown with orange tinge; paraphysis tips curved to hooked, \pm enlarged, 2.5-4.5 $\mu \mathrm{m}$ thick, most of them with knobs on the underside, some even with true branches; spores 11.0-13.0 $\times$ 7.0-7.5 $\mu \mathrm{m}$, oblong to narrowly ellipsoid. O. myosotis occurs late in the autumn gregariously in spruce needles.

Otidea microspora (Kanouse) Harmaja, n. comb. (Otidea alutacea var. microspora Kanouse, Mycologia 41: 668. 1949.). - Type $(\mathrm{MICH})$ examined. - By the virtue of its pale yellow more or less truncate apothecia and very short spores this taxon no doubt deserves to be recognized at the specific level.

Otidea propinquata (Karst.) Harmaja, n. comb. (Peziza propinquata Karsten, Not. Sällsk. F. Fl. Fennica Förh. 10: 110. 1869.) Lectotype (selected by NANNFELDT 1966), deposited in $\mathrm{H}$, examined. - NANNFELDT (1966) determined this specimen incorrectly as $O$. caligata (Nyl.) Sacc. and consequently considered Karsten's species as a synonym of $O$. caligata. According to my examination of the lectotype, a specimen on which certainly the description of $P$. propinquata was mainly based, it represents another and rather different-looking species, viz. that called $O$. abietina or $O$. indivisa Vel. $P$. propinquata thus provides a much older specific name for the conspicuous Otidea with entire apothecium, large spores and profusely lobed paraphysis tips. Peziza (Otidea) abietina would take priority even over Karsten's name but it is not available for this species (NANNFELDT 1966).

Acknowledgements. - The Directors of the herbaria in Uppsala (UPS) and Ann Arbor (MICH) arranged the loans of some specimens needed for this study, for which I owe them my gratitude. The University of Helsinki provided me with a long-term grant for research work.

\section{REFERENCES}

DISSING, H. 1966: The genus Helvella in Europe with special emphasis on the species found in Norden. - Dansk Bot. Ark. 25: 1-172.

HARMAJA, H. 1973: Amendments of the limits of the genera Gyromitra and Pseudorhizina, with the description of a new species, Gyromitra montana. - Karstenia 13: 48-58.

- 1976: Paradiscina Benedix - a synonym of Gyromitra Fr. - Karstenia 15:33-35.
MCKNIGHT, K. H. 1969: A note on Discina. Mycologia 61: 614-630.

- 1971: On two species of false morels (Gyromitra) in Utah. - Great Basin Nat. 31: 35-47.

MCKNIGHT, K.H. \& BATRA, L. R. 1974: Scanning electron microscopy in taxonomy of gyromitroid fungi. - Michigan Bot. 13: 51-64.

NANNFELDT, J. A. 1966: On Otidea caligata, O. indivisa and $\mathrm{O}$. platyspora (Discomycetes Operculatae). - Ann. Bot. Fennici 3: 309318. 